\title{
Land Flooding Effect Before and After Planting on Rice Yield in the System of Rice Intensification
}

\author{
Indra Dwipa $^{\mathrm{a}, 1}$, Musliar Kasim ${ }^{\mathrm{a}}$, Nalwida Rozen ${ }^{\mathrm{a}}$, Nurhamidah Nurhamidah ${ }^{\mathrm{b}}$ \\ ${ }^{a}$ Department of Crop Science, Faculty of Agriculture, Andalas University, Padang, West Sumatra, 25163, Indonesia \\ Email: ${ }^{1} 1965$ indradwipa@gmail.com \\ ${ }^{b}$ Department of Civil Engineering, Faculty of Engineering, Andalas University, Padang, West Sumatra, 25163, Indonesia \\ Email: nurhamidah@eng.unand.ac.id
}

\begin{abstract}
Rice is the primary carbohydrate source for half world population, particularly for Asian people, and rice demand also increases for non-Asian people. Rice provides the bulk daily calories for humans and animals. One of the problems in SRI method is weed. Many efforts to control weed in the SRI method and one of the way island flooding before planting. The objective of the research was to study the land flooding effect before planting in controlling weed to yield components of several rice varieties. The research was conducted in farmer land of Kuranji and Laboratory of Weed Science, Department of Crop Sciences, Faculty of Agriculture, Andalas University, Padang, West Sumatera, Indonesia from June to September 2019. A randomized block design was used in the experiment. 5 rice varieties (Batang Piaman, Panca Redek, PB 42, Batang Pasaman, and Saganggam Panuah) were used as treatments. The treatments were replied three times. Generally, the result showed that land flooding before planting affected the yield component of rice. For the length of the panicle, Panca Redek and Saganggam Panuah were the best variety $(30.18 \mathrm{~cm}$ and 20.91 $\mathrm{cm}$, respectively). For the weight of 1000 grains, Batang Piaman was the best variety (35.67\%), and Batang Piaman was also the best variety for the weight of dry grain (28.33). For production per hectare, Batang Pasaman, Batang Piaman, and Saganggam Panuah were the best variety (5.04 ton, 4.92 to and 3.88 tons respectively).
\end{abstract}

Keywords - land flooding; rice; system of rice intensification.

\section{INTRODUCTION}

Rice is the leading staple food of almost Asian people, particularly in Eastern and Southern Asia [1]. Rice contributes more than $22 \%$ of global energy [2]. Asia is the leading rice producer, and it produces $92 \%$ of the total of world rice production [3]. Over two billion people in Asia alone derive $80 \%$ of their energy needs from rice, which contains $80 \%$ carbohydrates, $7-8 \%$ protein, $3 \%$ fat, and $3 \%$ fiber [4]. For Asian people, rice is the dominant carbohydrate source even though it varies among the countries. For calorie intake, rice contribution is still high. In Laos and Myanmar, rice consumption per capita per year is $179 \mathrm{~kg}$ and $190 \mathrm{~kg}$, respectively. For Indonesia, it is still 142 $\mathrm{kg} /$ year. For iron intake, several Asian countries such as Bangladesh and the Philippines, rice contributes $40-55 \%$ for the low-income community. For Indonesia, rice contributes $63 \%$ of total energy intake, $38 \%$ for protein and $21.5 \%$ for iron [5].

Indonesia is an agricultural country with a wide land area. Most of the food source is from carbohydrate sources such as maize, rice, and tubers. $56 \%$ of rice production is from
Java island, 22\% from Sumatera, $10 \%$ is Sulawesi, $5 \%$ is Borneo, and $4 \%$ from other islands [6].

In Western Indonesia, particularly in Sumatera island, West Sumatera is one of rice producers [6]. West Sumatera is one region in Indonesia that passed by the equator line. This condition causes this region has many potential local rice varieties. In West Sumatera, rice is the main staple food and as a main cultivated plant. Rice cultivation can be conducted in low land, highland, dry land, and swampland [7].

The main problem in Indonesia is the rice production is not sufficient to provide the national rice requirement. The increasing of Indonesia population caused it. The increasing the population is not followed by land increasing for rice cultivation. This condition causes Indonesia should import rice from neighbor countries, Thailand, and Vietnam. Recently, in 2018, Indonesia imported 1.8-million-ton rice [6], a large number for Indonesia, a country that is known as an agricultural country, a country in the 80 s as rice exporter country. The Indonesian government has conducted many efforts to increase rice production. One of them is adopting technology, such as the System of rice intensification (SRI)[8]. 
SRI is a rice plant cultivated innovation method that was developed since the 1980s in Madagascar, Africa. This method presents one seedling for one hole, planting the seedling in 7-14 days after seeding, a wider space planting $(30 \times 30 \mathrm{~cm})$, and intermittent rice irrigation without flooding in the rice field [9]. This method also introduces a way to improve the growth and development of rice plants through water management and low external input [10]. Some research revealed that the SRI method could increase rice production by up to $72 \%$ than the conventional method [11]. For West Sumatera local rice variety, Batang Anai, the productivity was 11 ton/hectare [12]. Over 50 countries of the world have adopted this method [8].

In the SRI method, the main problem in weed. Weed presence in the rice field could reduce yield up to $87 \%$ [13]. The loss yield was caused by the competition between weed and cultivated plants in absorbing nutrients, water, sunlight, and growth space. A secondary metabolic, called allelopathy that is released by weed, suppresses the plant growth. Weed also become pest, and disease hosts [14].

In supporting the Indonesian government program to not using synthetic herbicide for controlling weed in SRI method causes to find another solution for controlling the weed. One of effort can be used to solve the problem is land flooding in sludging before planting [12]. Sludging is soil aggregate breakdown to be a smaller size in standing water condition. This condition caused the weed seeds could not grow even died. The oxygen in the logged condition caused it was so low. The water and oxygen availability were significantly affected the weed seed growth. It was closely correlated to the metabolism that occurred in the seed. If weed seed could obtain optimal oxygen and water, this condition activated the enzymes so that it increased the gibberellin, and finally, the seed could germinate. However, in standing water condition, the oxygen level is so low so that the seed could not germinate due to respiration did not occur but fatty acid oxidation and protein denaturation occurred in this condition so that the seed was broken and died [15]. Several types of research also showed that land flooding increased the yield components of rice [16][17]. Interval time of two days of land flooding affected $98.85 \%$ of the dry weight of grain, and production per hectare [18]. This objective of the study was to analyze the flooding time effect in controlling weed to components of the yield of rice varieties in the SRI method.

\section{MATERIALS AND METHOD}

The research was conducted in the farmer land of Kuranji (Figure 1) and Laboratory of Weed Science, Department of Crop Science, Agriculture Faculty, University of Andalas, Padang, West Sumatera, Indonesia from June to September 2019. A randomized block design was used in the experiment. 5 local rice varieties (Batang Piaman, Panca Redek, PB 42, Batang Pasaman, and Saganggam Panuah) were used as treatments.

The treatments were replied 3 times. Plots sized $2 \times 1 \mathrm{~m}$ used as rice planting. The rice plants yield of the plots used to measure the yield in this assay. Sowing field (sized $3 \times 3 \mathrm{~m}$ ) used for rice seeding. The rice seeds were grown in this field and waited for 12 days after planting (DAP). After 12 DAP, the seedlings from the sowing field were moved to the main plot. $20 \times 20 \mathrm{~m}$ of field size was used in this assay. The land for treatment was flooded for 21 days before planting.

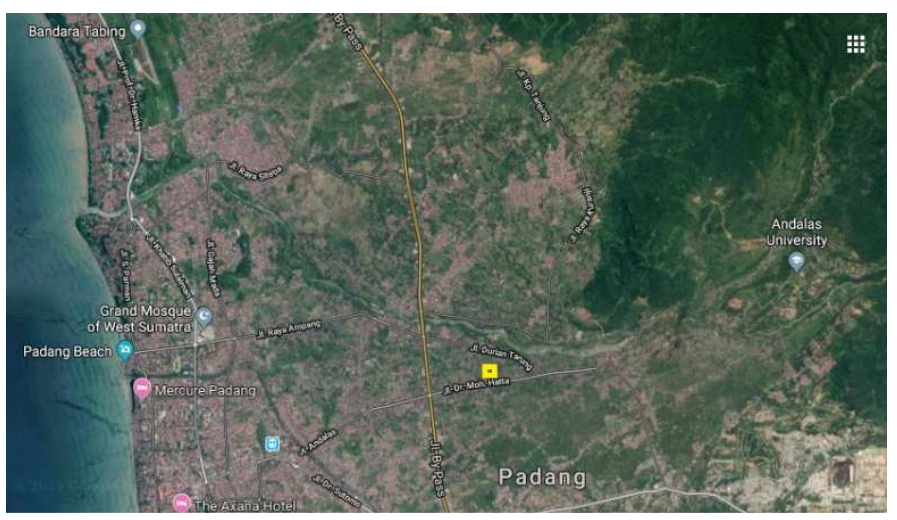

Fig. 1. Location of research in Padang (yellow square)

All seedlings were planted at the same time for all plots. The plant spacing was $25 \times 25 \mathrm{~cm}$. The fertilization was applied 3 times for urea $(0.42 \mathrm{~g} / \mathrm{plant})$. It was conducted on planting time, $32 \mathrm{DAP}$ and $49 \mathrm{DAP}$. The TSP and $\mathrm{KCl}$ fertilizer $(0.625 \mathrm{~g} / \mathrm{plant})$ also used in the assay. They were only applied in planting time. The growth of the plant was observed every day until the yield of rice was obtained. The observed parameters were yield components such as panicle length, grain number, and the number of pithy grains per panicle, 1000 grains weight, and production per hectare. Duncan's New Multiple Range Test analyzed the data at 5\%.

\section{RESULT AND DISCUSSION}

\section{A. Length of panicle}

Five rice varieties were examined in the assay showed that Panca Redek and Saganggam Panuah were the best varieties for the length of panicle than other varieties (Table 1). The length of panicle can be seen in Figure 2.

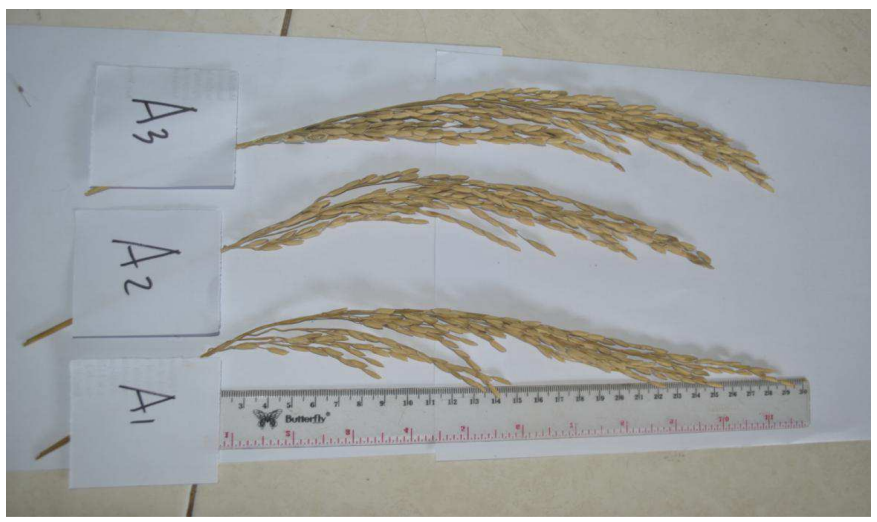

Fig. 2. Length of a panicle of 5 rice varieties inland flooding before planting treatment

Genetic variety played an important role in the length of panicle [19]. The addition of panicle length was affected by the addition of tiller number that produced panicles. If a little number of the tiller, the formed length of the panicle was shorter. The increase of panicle length affected the yield. This condition, due to each panicle, affected the branches of grain stalk that produced more grain [20]. 
TABLE I

LENGTH OF PANICLE OF 5 RICE VARIETIES INLAND FLOODING BEFORE PLANTING TREATMENT (CM)

\begin{tabular}{|l|lc|}
\hline \multicolumn{1}{|c|}{ Varieties } & \multicolumn{2}{|c|}{ Length of panicle $(\mathrm{cm})$} \\
\hline Panca Redek & 30.18 & $\mathrm{a}$ \\
\hline Saganggam Panuah & 20.91 & $\mathrm{a}$ \\
\hline Batang Pasaman & 28.04 & $\mathrm{ab}$ \\
\hline Batang Piaman & 27.93 & $\mathrm{ab}$ \\
\hline PB 42 & 25.77 & $\mathrm{~b}$ \\
\hline CoD $=5.02 \%$ & \\
\hline
\end{tabular}

The length of a panicle of rice in SRI method was longer than the conventional method [8]. In the SRI method, the population of the plant in one hole was the only one plant so that there was no competition between seedling in one hole. The reduction of plant population affected the length of plant panicle increasing due to no competition occurred among the plant in obtaining the sunlight, water, and nutrients [21].

The water requirement of the plant was determined by several factors such as soil types, soil fertility, climate, plant age and the rice variety. The highest water requirement for rice plant is at land preparation for planting and entering the grain filling stage. The plant spacing $25 \times 25 \mathrm{~cm}$ inland flooding for 35 after planting was effective in increasing the plant height than the conventional method [22].

The length of a panicle of a local best variety than previously reported was Pandan Wangi $(24.33 \mathrm{~cm}$ and 22.67 cm) [23][24]. In the research, Panca Redek and Saganggam Panuah were the best varieties for panicle length $(30.18 \mathrm{~cm}$ and $20.91 \mathrm{~cm}$, respectively). Panicle length of rice in SRI method was much better than the conventional method. In the SRI method, a plant for a planting hole increased the panicle length. This condition caused by no competition occurred to get sunlight among the plants [8]. Many reports revealed that many genes influenced panicle length. This gene controlled the rice plant genetic characteristic. One of these genes was OsGRF42 [25]. This gene encoded a growth-regulating that positively regulated the shape of grain and length of panicle and negatively regulated seed shattering. Higher expression of OsGRF4 was correlated to larger grain, longer panicle, and lower seed shattering. A unique OsGRF4 mutation, which occurred at the OsmiRNA396 target site of OsGRF4, seemed to be associated with high levels of OsGRF4 expression and results in phenotypic difference. Further research showed that OsGRF4 regulated two cytokinin dehydrogenase precursor genes (CKX5 and CKX1). It is resulting in increased cytokinin levels, which might affect the panicle traits. High storage capacity and moderate seed shattering of OsGRF4 may be useful in high-yield breeding and mechanized harvesting of rice. The finding provided additional insight into the molecular basis of rice panicle growth.

\section{B. Number of Grains Per Panicle and Number of Pithy Grain per Panicle}

The result showed that the land flooding for 21 days did not affect the number of grains per panicle of rice. The data and figure of grain number can be seen in Table 2 and Figure 3 . The number of rice grain was dominantly affected by genetic factors. The other factors that affected the number of grains were abiotic and biotic factors [23]. The grain was affected by the suitability of planted varieties, the presence and severity of pest and disease and environmental factors [27].

The genetic factor played the main role in the amount of grain per panicle. It covered physiology, morphology and resistance to pest and disease. Each physiology characteristic affected the yield in various ways such as plants physiology efficiency in yield, including the failure level and sterility of grain. Qin et al [28] added that there was a gene controlled the grain of rice, called $L T B S G 1$. The other report revealed a gene, OSSPL18 controlled grain weight and grain number of rices [29]. Wang et al. [30] also stated that there were 19 genes as a candidate that controlled the rice grain. Many genes were reported in controlling the grain of rice, and it indicates there are still more other genes that were not found yet.

The amount of grain was correlated to several tillers. Besides the effect of population density in one hole, the tiller formation was affected by genetic and environmental factors. The plant used more assimilate for stem and left formation than tiller [8]. A maximum tiller can be obtained if the plant had a suitable genetic and environment for the growth and development of the plant. The maximum tiller was also affected by planting space due to planting space determined the solar radiation, mineral, and the cultivation of plant itself. However, genetic and environmental factor was the main factor that affected the tiller formation [31].

TABLE II

Number Of GRain PeR PANicle Of 5 Rice VARIETIES INLAND FloOding Before Planting TREATMENT

\begin{tabular}{|l|c|}
\hline \multicolumn{1}{|c|}{ Varieties } & Number of grain \\
\hline Batang Pasaman & 198.92 \\
\hline Batang Piaman & 189.42 \\
\hline Saganggam Panuah & 180.50 \\
\hline PB 42 & 170.25 \\
\hline Panca Redek & 149.58 \\
\hline CoD $=16.29 \%$ & \\
\hline
\end{tabular}

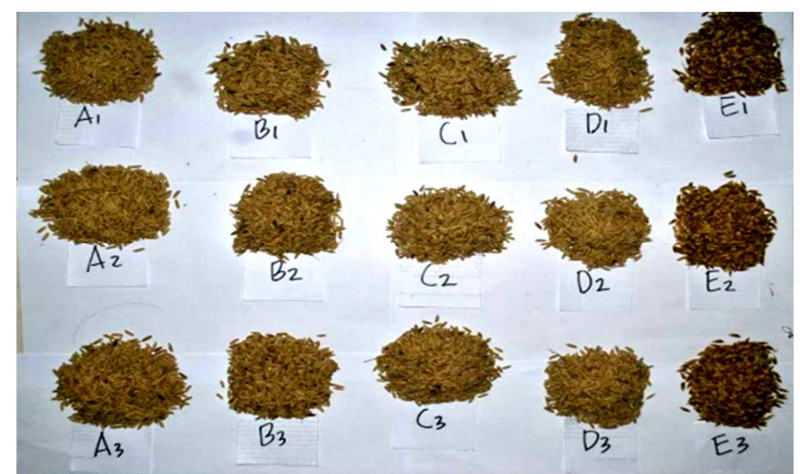

Fig. 3. Number of grains per panicle of 5 rice varieties inland flooding before planting treatment

The amount of grain was closely related to several pithy grains per panicle. The result also showed that the land flooding before planting did not affect the number of a pithy grain of rice (Table 3). Agroecology factors affected the rice grain, such as seed quality, cultivation technique, climate and weather, and pest and disease attack. The seed quality 
affected the viability and vigor of seeds. The high vigor and viability of seed caused it could emerge rapidly and uniform in a highly diverse environment and produced the more vigorous seeds. The seed quality was affected by the cultivation method, seed treatment (drying, cleaning, and sorting), storage time, and seed age [23].

The other factors that could affect the grain quality were soil fertility, rainfall, humidity, fertilizer application, seedling selection, and pest and disease [33]. For pest and disease disruption, fungi are the main problem in the storage of grain after harvesting. In this case, water content played an important role in obtaining a high quality of seed. Excessive water is a suitable condition for fungi to grow and develop rapidly [34].

TABLE III

NUMBER OF PITHY GRAIN PER PANICLE OF 5 RICE VARIETIES INLAND FLOODING BEFORE PLANTING TREATMENT

\begin{tabular}{|l|c|}
\hline \multicolumn{1}{|c|}{ Varieties } & Number of pithy grains \\
\hline Batang Pasaman & 168.92 \\
\hline Batang Piaman & 167.17 \\
\hline Saganggam Panuah & 163.67 \\
\hline PB 42 & 130.25 \\
\hline Panca Redek & 115.58 \\
\hline CoD $=16.39 \%$ & \\
\hline
\end{tabular}

Several panicles were correlated to harvesting age and weight of 1000 grain. It describes the selection of shorter flowering time of plant will produce shorter harvesting age, but the grain size was small. The amount of grain per panicle was positively correlated to several pithy grain and length of the panicle. More number of grain panicle produced more pithy grain per panicle. On the other side, a more significant number of grains was produced by longer panicles [35].

The plant management could control the tiller formation so that the plant could increase the grain formation. The tiller formation was affected by phosphorus application, and the panicle of the plant in wider planting space produce more tiller than denser planting space. Besides, cytokinin stimulated tiller formation, mainly the biosynthesis result of tiller internodes [36].

\section{Weight of 1000 grains}

According to the result, Batang Piaman was the best variety for the weight of 1000 grains (33.67 gram) (Table 4). Each variety had a certain characteristic in producing the weight again. Weight of 1000 grains was affected by palea and lemma size [37]. This parameter was the feature of a variety of stability. The size of palea and lemma determined its size. The pithy grain was also affected by grain size, but it was determined during the release of the panicle [38].

TABLE IV

WEIGHT Of 1000 GRAINS OF 5 Rice VARIETIES INLAND FLOOdING BEFORE PLANTING TREATMENT (GRAM)

\begin{tabular}{|l|ll|}
\hline \multicolumn{1}{|c|}{ Varieties } & \multicolumn{2}{|c|}{ Weight of 1000 grains (gram) } \\
\hline Batang Piaman & 35.67 & a \\
\hline Saganggam Panuah & 32.00 & b \\
\hline Batang Pasaman & 30.33 & $\mathrm{c}$ \\
\hline Panca Redek & 26.27 & $\mathrm{c}$ \\
\hline PB 42 & 26.33 & $\mathrm{c}$ \\
\hline CoD $=5.02 \%$ & \multicolumn{2}{c}{} \\
\hline
\end{tabular}

Note: Different letter indicate a significant difference
Grain formation was affected by nitrogen. Nitrogen is one of the main elements in chlorophyll formation, a pigment for supporting the photosynthesis process. Carbohydrate as result of this process was used for cell division and stimulated the grain formation. For rice plants, the tiller and leaves supported high grain production. The weight of grains was also affected by the quality of rice seeds [39].

From the genetic side, grain weight, including grain length and grain width, is a complex trait, and hundreds of quantitative trait loci (QTLs) were detected in different genetic rice populations. However, only about ten genes have been isolated and characterized until now. Nine QTLs for grain size were identified by genome-wide association study in a natural rice population. The novel grain size gene $O s S N B$ was identified from $q G W 7$ based on the difference of expression levels between two different varieties with significantly different grain width. OsSNB is an AP2 transcription factor that was negatively regulated grain size. However, OsSNB regulated the transition from the spikelet meristem to the floral meristem and the floral organ development in a previous study [40].

\section{Weight of the dry grain}

Twenty-one days of land flooding before planting affected the weight of dry grain. According to the result, Batang Piaman was the best variety for the weight of dry grain (Table 5). The planting space treatment affected the production of rice. This process occurred due to many other factors affected the growth and development of plants such as rainfall, pest attack, death tiller, or unproductive tiller. The main factor that affected the weight of dry grain was a growth factor such as sunlight, water, and CO2 [41].

TABLE V

WeIGHT OF DRy GRAIN OF 5 Rice VARIETIES INLAND FLoOding BEFore Planting TREATMENT (GRAM)

\begin{tabular}{|l|ll|}
\hline \multicolumn{1}{|c|}{ Varieties } & \multicolumn{2}{|c|}{ Weight of dry grain (gram) } \\
\hline Batang Piaman & 28.33 & a \\
\hline Batang Pasaman & 26.00 & b \\
\hline Saganggam Panuah & 23.33 & c \\
\hline Panca Redek & 22.33 & c \\
\hline PB 42 & 22.00 & c \\
\hline CoD $=5.93 \%$ & \multicolumn{2}{|l}{} \\
\hline
\end{tabular}

The dry weight reflected the nutrients status that was absorbed by the plant. The dry weight was the nutrient composition of plant tissue without the water content. Dry weight represented the standard of plant nutrition due to it depended on photosynthesis. Grain weight was closely related to yield. In the Graminae family, the dry matter was particularly in the endosperm [42]. The substance of endosperm was from carbohydrate that was formed before panicle formation. The carbohydrate formation depended on nutrients availability and environmental factor that played an important role in metabolism [43] - the high and low dry weight depending on dry matter of plant. The dry matter generally consisted of carbohydrates, protein, and fat [44].

Dry grain affected the quality of rice. Rice storage could change the chemical composition of rice. The chemical change was closely related to enzymatic reactions that occurred in starch, protein, and rice lipids. This process was 
catalyzed by $\alpha$-amylase and $\beta$-amylase, protease, lipase, and lipoxygenase [45]. Typically, the water content of the dry grain is $14 \%$ [46]. After harvesting, the water content of grain was $22-9-29,1 \%$ [47], and some processes could be done to decrease of water content by up to $14 \%$.

\section{E. Production per plot and hectare}

According to the result, Batang Pasaman, Batang Piaman, and Saganggam Panuah were the best varieties for production per plot. The production per plot was $2.02 \mathrm{~kg}$, $1.97 \mathrm{~kg}$, and $1.55 \mathrm{~kg}$, respectively (Table 6). The different result of yield was dominantly caused by genetic factor. The production of rice was affected by two factors, internal and external. The internal factor was the factor that was affected by genetic or heredity such as plant age, morphology, yield, the capacity to store the food reserves, and resistance to pest and disease. The external factor was the environmental factor such as climate and soil. The internal factor or genetic was the specific factor that depended on the plant itself [48].

TABLE VI

PRODUCTION PER Plot of 5 RICE VARIETIES INLAND FLOODING BEFORE Planting TREATMENT (GRAM)

\begin{tabular}{|l|ll|}
\hline \multicolumn{1}{|c|}{ Varieties } & \multicolumn{2}{|c|}{ Production per plot $(\mathrm{kg})$} \\
\hline Batang Piaman & 2.02 & $\mathrm{a}$ \\
\hline Batang Pasaman & 1.97 & $\mathrm{a}$ \\
\hline Saganggam Panuah & 1.55 & $\mathrm{a}$ \\
\hline Panca Redek & 0.93 & $\mathrm{~b}$ \\
\hline PB 42 & 0.90 & $\mathrm{~b}$ \\
\hline CoD $=19.19 \%$ & & \\
\hline
\end{tabular}

Note: Different letter indicate a significant difference

The production per plot affected the production per hectare. Batang Pasaman, Batang Piaman, and Saganggam Panuah were the best varieties for production per hectare. The production per hectare of each variety was 5.04 ton, 4.92 ton, and 3.88 ton, respectively (Table 7). Several factors affected the production per hectare of rice, such as soil fertility, rainfall, humidity, fertilization, seedling selection, cultivation method, pest, and disease [49].

The production per hectare is the leading indicator of rice superior varieties. According to the description of varieties, the result of the research was still lower than the description. For Batang Piaman and Batang Pasaman varieties, the yield potency is $7.6 \mathrm{ton} /$ hectare and an average of yield 6.0 ton/hectare [50]. For Saganggam Panuah, the potency of yield is 8.8 ton/hectare [51]. The one factor that could decrease rice yield is the abiotic factor, and one of them is rice bug (Leptocorisa acuta, Hemiptera: Alydidae)[52][53]. The symptom and damage caused by the pest and adult, the grain is empty due to the bug sucked when the grain is till mature. This pest also could suck the stem liquid. The sucked stem became empty and blackish brown. The stink bug sucked the grain liquid by its stylet [54]. The nypmh was more active than an adult, but the adult destroyed rice plant more because its life span was more prolonged than nymph. The loss of grain liquid caused the grain to become smaller. In immature grain condition, it attacked the hardening grains so that when stylet penetrated, it released the enzyme that could digest the carbohydrate [55], [56]. The low yield of the research is required to analyze more to find the solution to get high yield by land flooding before planting in controlling the weed in the SRI method.

TABLE VII

PRODUCTION PER HeCtARE of 5 Rice VARIETIES INLAND FloOding BEFORE PLANTING TREATMENT (GRAM)

\begin{tabular}{|l|ll|}
\hline \multicolumn{1}{|c|}{ Varieties } & \multicolumn{2}{|c|}{ Production per hectare (ton) } \\
\hline Batang Piaman & 5.04 & $\mathrm{a}$ \\
\hline Batang Pasaman & 4.92 & $\mathrm{a}$ \\
\hline Saganggam Panuah & 3.88 & $\mathrm{a}$ \\
\hline Panca Redek & 2.33 & $\mathrm{~b}$ \\
\hline PB 42 & 2.25 & $\mathrm{~b}$ \\
\hline CoD $=19.19 \%$ & \multicolumn{3}{|}{} \\
\hline
\end{tabular}

Note: Different letter indicate a significant difference

\section{CONCLUSIONS}

Generally, before planting, the land flooding affected the yield component of rice. The land flooding affected the panicle length, the 1000 grains weight, the weight of dry grain, and production per hectare. For the length of the panicle, Panca Redek and Saganggam Panuah were the best variety $(30.18 \mathrm{~cm}$ and $20.91 \mathrm{~cm}$, respectively). For the weight of 1000 grains, Batang Piaman was the best variety (35.67\%), and Batang Piaman was also the best variety for the weight of dry grain (28.33). For production per hectare, Batang Pasaman, Batang Piaman, and Saganggam Panuah were the best variety (5.04 ton, 4.92 to and 3.88 tons respectively).

\section{ACKNOWLEDGMENT}

We would like to thank Andalas University, Indonesia, which funded the research through the Research Center and all participants who helped this study.

\section{REFERENCES}

[1] A. Rohman, S. Helmiyati, M. Hapsari, D.L. Setyaningrum, "Rice in health and nutrition" International Food Research, vol.. 21, pp. 1324, June 2014

[2] P.V.D. Eng,"Productivity and comparative advantage in rice agriculture in Southeast Asia since 1870 ", Asian Economic Journal, vol. 18 , issue 4, pp. 1-29, May 2004

[3] P.R. Chaudhari, N. Tamrakar, L. Singh, A. Tandon, D. Sharma, "Rice nutritional and medicinal properties : A review article ", Journal of Pharmacognosy and Phytochemistry, vol. 7, issue 2, pp. 150-156, June 2018

[4] S. Bhosale, D. Vijayalakshmi," Processing and nutritional composition of rice bran", Current Research in Nutrition and Food Science, vol. 3, issue 1, pp 74-80, March 2015

[5] T. Laiprakobsup, "The policy effect of government assistance on the rice production in Southeast Asia : Comparative case studies of Thailand, Vietnam, and the Philippines", Development Studies Research, vol. 6, issue 1, pp. 1-12, October 2018

[6] Statistics Indonesia, “ Indonesia in figures 2018", Statistics Indonesia. September 2019

[7] M.J. Uddin, K.M.M. Billah, G.R. Akanda, M.H. Prince, M.M. Rahman, M.M.P. Sumon, N.H. Antor, "Farmer's knowledge on modern rice cultivation technique at Dumki Upazilla", International Journal of Advantages in Agricultural Sciences", vol. 2, issue 10, pp. 1-7, October 2017

[8] A.P. Mondol, P.K Biswas, M.S. Islam, "Performance of system of rice intensification with conventional method of rice cultivation", Bangladesh Agron J., vol. 20, pp. 75-80, June 2017

[9] N. Hidayati, Triadiati, I. Anas, " Rooting system of rice cultivated under system rice of intensification (SRI) method which improving rice yield", Hayati, vol. 25, issue 2, pp. 63-69, April 2018 
[10] M. Hasan, S. Sato, "Water saving for paddy cultivation under system of rice intensification (SRI) in eastern Indonesia", J. Tanah dan Lingkungan, vol. 9, pp. 57-62, June 2007

[11] S. Anitha, M. Chellappan, " Comparison of the system of rice intensification (SRI), recommended practices, and farmer's method of rice (Oryza sativa L.) production in the humid tropics of Kerala, India", Journal of Tropical Agriculture, vol. 49, issue 1, pp. 64-71, April 2011

[12] N. Rozen, "Mechanism of rice field tolerance to weed in SRI method", Ph.D Thesis, Andalas University, Padang, Indonesia, June 2008

[13] S. Utami, L.R. Purdyaningrum, "Struktur Komunitas Gulma Padi (Oryza sativa L.) sawah organik dan sawah anorganik di desa Ketapang, kecamatan Susukan, Kabupaten Semarang”, Bioma, vol. 14, issue 2, pp. 91-95, December 2012

[14] S. Darmanti, Santosa, K. Dewi, L.N. Nugroho, "Allelopathic effect of Cyperus rotundus L. on seed germination and initial growth of Glycine $\max$ L. cv. Grobogan", Bioma, vol. 17, issue 2, pp. 61-67, December 2015

[15] A.M. Latare, S.K. Singh, " Effect of sewage sludge and fertilizers application on accumulation of heavy metals and yield of rice (Oryza sativa L.) in an inceptisol of Varanasi", Journal of The Indian Society of Soil Science, vol. 61, issue 3, pp. 219-225, March 2013

[16] R.A. Laksono, Y. Irawan, "Effect of planting system and flooding on productivity of paddy cultivar Mekongga in Karawang district", Jurnal Kultivasi, vol. 17, issue 2, pp. 639-647, August 2018

[17] L.S. Supriatin, A. Basukriadi, M.H. Thayeb, T.E.B. Soesilo, "The flooding effect from rice cultivation technique o infiltration and water balance", Forum Geografi, vol. 27, issue 1, pp. 33-44, July 2013

[18] M. Khairi, M. Nozulaidi, A. Afifah, M.S. Jahan, "Effect of various water regimes on rice production in lowland irrigation", Australian Journal of Crop Science, vol. 9, issue 2, pp. 153-159, August 2015

[19] E. Liu, Y. Liu, G. Wu, S. Zeng, T.G.T. Thi, L. Liang, Y. Liang, Z. Dong, D. She, H. Wang, I.U. Zaid, D. Hong, "Identification of a candidate gene for panicle length in rice (Oryza sativa L.) via association and lingkage analysis", Frontiers in Plant Science, vol. 7 , issue 596, pp. 1-13, May 2016

[20] N. Cox, L.M. Smith, “ A rice transcription factor controls grain length through cell number", Plant Physiology, vol. 180, issue 4, pp. 1781-1783, July 2019

[21] Nurhasanah, Sadaruddin, W. Sunaryo, “ Yield related traits characterization of local upland rice cultivars originated from East and North Kalimantan, Indonesia," Biodiversitas, vol. 18, issue 3, pp. 1165-1172, July 2017

[22] A. Sauki, A. Nugroho, Roedy Soelistyono, The effect of plant densities and time in SRI method (System of rice intensification) to growth and results for rice Oryza sativa L.)", Jurnal Produksi Pangan, vol. 2, issue 2, pp. 121-127, March 2014

[23] W.A. Suryanegara, Supriyanta, Kristamtimi, " The performance of ten local rice (Oryza sativa L.) cultivars of Yogyakarta special territory,"Vegetalika, vol 6. pp. 55-70, April 2014

[24] Kristamtini, S. Widodo, E.W. Wiranti, Sutarno, "Crops and consumer preferences of 20 local rice genetic resources of Yogyakarta, Indonesia," IOP Conf. Series: Earth Environ. Sci., vol. 215, pp. 1-7., October 2019

[25] P. Sun, W. Zhang, Y. Wang, Q. He, F. Shu, "OsGRF4 controls grain shape, panicle length and seed shattering in rice", J. Integr. Plant Biol., vol. 58, pp. 836-847, June 2016

[26] M.R. Ansari, T. Shaheen, S.A. Bukhari, T. Husnain, " Genetic improvement of rice for biotic and abiotic stress tolerance," Turkish Journal of Botany, vol. 39, pp. 911-919, October 2015

[27] X. Li, L. Wu, X. Geng, X. Xia, X. Wang, Z. Xu, Q. Xu, Deciphering the environmental impacts on rice quality for different rice cultivated areas," Rice, vol. 11, issue 7, 1-10, January 2019

[28] R. Qin, D. Zheng, C. Yang, D. Akhter, M. Alamin, X. Jin, C. Shi, " LTBSG1, a New Allele of BRD2, Regulates Panicle and Grain Development in Rice by Brassinosteroid Biosynthetic Pathway,"Genes, vol. 9, issue 292, 1-22, June 2018

[29] H. Yuan, P. Qin, L. Hu, S. Zhan, S. Wang, P. Gao, J. Li, M. Jin, Z. $\mathrm{Xu}$, Q. Dao, A. Du, B. Tu, W. Chen, B. Ma, Y. Wang, S. Li, " OsSPL18 controls grain weight and grain number in rice," Journal of Genetics and Genomics, vol. 46, issue 1, pp. 41-51, January 2019

[30] S. Wang, K. Wu, Q. Qian, Q. Liu, Y. Pan, Y. Ye, X. Liu, J. Wang, J. Zhang, S. Li, Y. Wu, X. Fu, " Non-canonical regulation of SPL transcription factors by a human OTUB1- like deubiquitinase defines a new plant type rice associated with higher grain yield, " Call Research, vol. 27, pp. 1142-1156, August 2017

[31] Y. Wang, T. Ren, J. Lu, R. Ming, P. Li, S. Hussein, R. Cong, X. Li, "Heterogeneity in rice tillers yield associated with tillers formation and nitrogen fertilizer", Agronomy Journal, vol. 108, issue 4, pp. 1717-1725, June 2016

[32] P. Wang, D. Li, L. Wang, B. Adhikari, " Effect of high temperature intermittent drying on rice seed viability and vigor," International Journal of Food Engineering, vol. 13, issue 10, pp. 1-12, August 2017

[33] S.S. Dipti, M.N. Bari, K.A. Kabir, " Grain quality characteristics of some Beruin rice varieties of Bangladesh", Pakistan Journal of Nutrition, vol. 2, issue 4, pp. 242-245, April 2003

[34] A. Sawane, M. Sawane, " Mycotoxigenicity of Aspergillus, Penicillium and Fusarium spp. Isolated from storage rice ", International Journal of Current Microbiology and Applied Sciences, vol. 3, issue 11, pp. 116-121, February 2014

[35] D. Rachmawati, W.N. Hanifah, Parjanto, A. Yunus, "Selection of short stem Mentik Susu rice M3 from gamma ray irradiation", IOP Publishing, vol. 250, pp. 1-7, October 2019

[36] X.X. Chen, W. Zhang, X.Y. Liang, Y.M. Liu, S.J. Xu, Q.Y. Zhao, Y.F. Du, L. Zhang, X.P. Chen, C.Q. Zhou, " Physiological and developmental traits associated with the grain yield of winter wheat as affected by phosphorus fertilizer management", Scientific Reports, vol. 9 , issue 16580 , pp. 1-12

[37] Z. Tian, J. Li, X. He, X. Jia, F. Yang, Z. Wang, "Grain Yield, Dry Weight and Phosphorus Accumulation and Translocation in Two Rice (Oryza sativa L.) Varieties as Affected by Salt-Alkali and Phosphorus", Sustainability, vol. 9, issue 1461, pp. 1-16, August 2017

[38] I.A. Mahmood,A. Ali,'Response of direct seeded rice and wheat crops to phosphorus application with crop residue incorporation in saline-sodic soil”, Int. J. Agric. Biol. Vol. 17, pp. 1219-1224, June 2015

[39] G. Kumar, L.V.S. Rao, K. Keshavulu, "Comparative Evaluation of Seed and Grain Quality Parameters of Rice (Oryza sativa L.) Varieties under SRI and Conventional Methods of Rice Cultivation," International Journal of Current Microbiology and Applied Sciences,"vol. 6, issue 8, pp. 3653-3660, June 2017

[40] X. Ma, F. Feng, Y. Zhang, I.E. Elesawi, K. Xu, T. Li, H. Mei, H. Liu, N. Gao, C. Chen, L. Luo, S. Yu, “ A novel rice grain size gene OsSNB was identified by genome-wide association study in natural population”, Plos Genetics, vol. 15, issue 5, pp. 1-20, May 2019

[41] A.B. Puteh, M.M.A. Mondal, M.R. Ismail, M.A. Latif, “ Grain sterility in relation to dry mass production and distribution in rice (Oryza sativa L.)", Biomed Research International, vol. 2014, pp. 16, May 2014

[42] S. Morita, J.I. Yonemaru, J.I. Takanashi, "Grain growth and endosperm cell size under high night temperature in rice (Oryza sativa L.)", Annals of Botany, vol. 95, issue 4, pp. 695-701

[43] D.R. Wang, E.J. Wolfrum, P. Virk, A. Ismail, A.J. Greenberg, S.R. McCouch, " Robust phenotyping strategies for evaluation of stem non-structural carbohydrates (NSC) in rice", Journal of Experimental Botany, vol. 67, issue 21, pp. 6125-6138

[44] T.R.S. Priya, A.R.L.E. Nelson, K. Ravichandran, U. Anthony, "Nutritional and functional properties of coloured rice varieties of South India ; a review", Journal of Ethnic Foods, vol. 6, issue 11, pp. $1-11$

[45] N. Thanathornvarakul, J. Anuntagool, K. Tananuwong, "Aging of low and high amylose rice at elevated temperature: Mechanism and predictive modeling", Journal of Cereal Science Journal, vol. 70, pp. 155-163, January 2016

[46] T. Millati, Y. Pranoto, N. Bintoro, T. Utami, “ The effect of storage temperature on freshly harvested wet grain to the physical quality change of milled rice", Agritech, vol. 37, issue 4, pp. 477-485, November 2017

[47] Ashar, M. Iqbal, " The management of post harvesting of rice varieties by rice milling unit (RMU)", Jurnal Galung Tropika, vol. 1, pp. 55-59, January 2013

[48] N.K. Fageria, "Yield physiology of rice", Journal of Plant Nutrition, vol. 30, issue 6, pp. 843-879, July 2006

[49] R. Ghadirnezhad, A. Fallah," Temperature effect on yield and yield components of different rice cultivars in flowering stage", International Journal of Agronomy, vol. 2014, issue 846707, pp.1-4, May 2014 
[50] Indonesian Agency for Agricultural Research and Development Ministry of Agriculture," Description of Batang Piaman," http://en.litbang.pertanian.go.id/, November 2019

[51] Indonesian Agency for Agricultural Research and Development Ministry of Agriculture," Description of Saganggam Panuah," http://en.litbang.pertanian.go.id/, November 2019

[52] F. Maulina, N. Nelly, Hidrayani, H. Hamid," Parasitizations Levels and Temperature Tolerance of Rice Bug (Leptocorisa oratorius Fabricius) Egg Parasitoids: Mass Rearing for Biological Control", International Journal on Advanced Science Engineering Information Technology, vol. 8, issue 3, pp. 714-719, June 2018

[53] A. Soren, R. Prasad, " Management of ear bug (Leptocorisa acuta Thunberg) infesting rice by host plant nutrients supplied through organic and inorganic sources with emphasis on use of neem and karanj cake", Journal of Pharmacognosy and Phytochemistry, vol. 2018, pp. 834-836, August 2018

[54] A. Sugimoto, L. Nugaliyadde," Damage of rice grains by rice bug, Leptocorisa acuta Fabricius (Heteroptera: Alydidae)", JIRCAS Journal, vol. 2, pp. 13-17, January 1995

[55] K. Gupta, A. Kumar," Field Efficacy of Certain Insecticides against Rice Gundhi Bug [Leptocorisa acuta (Thonberg)] Under AgroClimatic Condition of Allahabad, India", International Journal of Current Microbiology and Applied Sciences, vol. 6, issue 8, pp. 343345, August 2017

[56] H.V. Berg, Soehardi, " The influence of the rice bug Leptocorisa acuta on rice yield", Journal of Applied Ecology, vol. 37, issue 6, pp. 959-970, December 2000 